\title{
Usability Telecontextual Study for Nursing Students: Unfolding Case Study
}

\section{Gina Nurdina1, Tri Antika Rizki Kusuma Putrí1, and Suci Noor Hayati ${ }^{2}$}

${ }^{1}$ Medical Surgical Nursing Department, STIKep PPNI Jabar, West Java, Indonesia

${ }^{2}$ Nursing Management Department, STIKep PPNI Jabar, West Java, Indonesia

ORCID:

Suci Noor Hayati: https://orcid.org/0000-0001-6252-481X

\section{Abstract}

Telecontextual study is a remote guidance method using an online platform to help students understand competency test materials and updates on nursing cases. This study aims to identify the platform's usability to increase critical thinking for prepared students facing UJIKOM. The design of this study was descriptive with a cross-sectional approach. The research population is 34 students of STIKep PPNI West Java. Data collection was done via the USE questionnaire with 13 statements. The method's

Corresponding Author: Suci Noor Hayati suci.noor@rocketmail.com

Publishing services provided by Knowledge E

(c) Gina Nurdina et al. This article is distributed under the terms of the Creative Commons

Attribution License, which

permits unrestricted use and

redistribution provided that the

original author and source are credited.

Selection and Peer-review under the responsibility of the IVCN Conference Committee.

S OPEN ACCESS useability was described with univariate analysis. The majority of respondents said this application was easy to apply (70.6\%). Almost all respondents stated that this application was suitable and improved the critical thinking skills of nursing students (91.2\%). Based on statistical tests, all respondents said that this application is easy to remember (100\%). More than half of the respondents stated that this application only had minor errors (67.6\%). All respondents remain satisfied with this application, although it needs improvement in several aspects (100\%). It can be concluded that this application has good usability, as evidenced by the high score of the five usability aspects. Application development by minimizing errors and fixing the settings following the user target is expected to increase this application's usability and readiness on a larger scale.

Keywords: Usability, Telecontextual, Unfolding Case Study

\section{Introduction}

Case-based learning is a teaching method that is often used to maximize critical thinking skills by matching clinical cases with the body of knowledge [1]. This high expectations method can improve students' clinical performance, attitude, and teamwork [1, 2, 17]. The ability to think critically in nursing includes analyzing, applying standards, discriminating, information seeking, logical reasoning, predicting, and transforming [3]. Being able to explore a case is an essential component in critical thinking. Analytical thinking is needed by nursing students to determine clinical issues that occur in the field. 
Students can use one of the case-based learning method like contextual study using an unfolding case. The unfolding case allows nursing students to analyze the needs for assessment, diagnosis, and nursing intervention by the given topic [4-6, 15]. The presented case can develop following each student's analysis to trigger students to explore a subject that occurs in the field $[4,6,7]$. Health programs like nutrition education and midwifery using this method to improve their students' performance and critical thinking $[8,9]$. Unfolding case methods already used this learning method is often used to support nursing students' performance in a laboratory setting [7].

The development of technology and demands for patient safety in nursing requires nurses to have qualified competencies Revolution 4.0 focuses on the use of technology in everyday life. Likewise, with the learning method for students who often have problems following the debriefing that has been prepared by educational institutions. This condition underlies the need for an innovative learning method in digitization to be easily accessible to students[10].

The current condition of Covid 19 requires distance learning with online learning methods so that students quickly access it. The use of an android-based online platform is an option for students with smartphone availability. Android allows users to install third-party applications, either obtained from application stores such as Google Play, Amazon Appstore, or by downloading and installing APK files from third-party sites. It is necessary to identify acceptability based on usability criteria to determine the application's use $[11,12]$.

Usability is part of the multi-disciplinary field of Human-Computer Interaction $(\mathrm{HCl})$. Human-Computer Interaction is a science field developed since 1970, which studies how to design a computer screen display in an information system application convenient for users to use. Usability comes from the word usable, which generally means to be used well. Something can be useful well, especially failure in its use can be eliminated or minimized and provide benefits and satisfaction to users. An online platform's usability test can use five components: learnability, efficiency, memorability, error, and satisfaction [13].

Learnability measures the level of ease of doing simple tasks when you first encounter a design. Efficiency measures the speed at which a particular task is performed after studying the system. Memorability looks at how quickly the user regains proficiency in using the design when it returns over time. Errors look at how many errors users have made, how serious they are, and how easy they are to resolve. Satisfaction measures the level of satisfaction in using the design. In this study, it is expected that the application's usability value can increase to compete with similar competitor applications. 


\section{Methods and Equipment}

\subsection{Methods}

\subsubsection{Research Design}

This research is a quantitative study used a descriptive method through with crosssectional approach. The population in this study were 34 students of STIKep PPNI Jabar nurses. The sampling technique used was total sampling. The inclusion criteria in this study were students who were willing to be research respondents. In this study, the minimum sample size needed was 34 students. The instrument used in this study was the USE questionnaire containing 13 statements. Lund develops USE includes three measurements to measure usability. The validity test results of Bahasa version of USE showed that the calculated r-value is more significant than 0.404 [11, 13]. Variable dimensions described using a 1-5 scale to obtain ordinal data (Table 1):

TABLE 1: Value

\begin{tabular}{|l|c|c|c|c|c|}
\hline PK & KMS & KM & CM & M & SM \\
\hline Value & 1 & 2 & 3 & 4 & 5 \\
\hline
\end{tabular}

Description:

$\mathrm{PK}=$ Question questionnaire $\quad \mathrm{CM}=$ Moderately Easy

$\mathrm{KMS}=$ Less Easy Once $\quad \mathrm{M}=$ Easy

$\mathrm{KM}=$ Less Easy $\quad \mathrm{SM}=$ Very Easy

Based on these definitions, usability is measured based on the components:

1. Ease (learnability) defined how quickly users are proficient in using the system and convenience to run a function and what the user wants they can get.

2. Efficiency (efficiency) is defined as the resources expended to achieve the goal's accuracy and completeness.

3. Easy to remember(memorability)defined how the traffic users maintain their knowledge after a certain period, Following the menu's ability to obtain.

4. Errors and security (errors) are defined as how many errors the user makes. The user's errors make cover a mismatch of what the user thinks with what the system represents. 
5. Satisfaction (satisfaction) is defined as freedom from discomfort, and positive attitudes towards the use of the product or subjective measures, as users feel about using the system.

\section{Results}

Univariate analysis in this study was used to describe the dependent variable.

1. Learnability used the online platform shows a value of $70.6 \%$, which means that some respondents consider the application easy to use in completing necessary tasks when they first see or deal with an existing system.

2. The efficiency of using the online platform shows a value of $91.2 \%$, which means that respondents think that the application can be used quickly in completing existing tasks when they first learn about the system.

3. Memorability of the online platform's use shows a value of $100 \%$, which means that respondents consider the application easy to use again after not using it for a while.

4. Errors for using the online platform show a value of $67 \%$, which means that few respondents experience errors or errors made by users and how easily they can solve them.

5. Satisfaction showed a $100 \%$ result, which means that all respondents are satisfied while using the system that has been created.

\section{Discussion}

Some respondents said this application was easy to apply (70.6\%). Learnability is defined as how fast the user uses the system and how easy it is to carry out a program's function. Almost all respondents stated that this application was right on its purpose to improve the critical thinking skills of nursing students (91.2\%). Efficiency is defined as the resources expended to achieve the accuracy and completeness of goals. Based on statistical tests, all respondents stated that this application is easy to remember (100\%). Memorability is defined as the user's ability to recognize the functions and menus in an application. More than half of the respondents stated that this application only had minor errors (67.6\%). Errors and security (errors) are defined as the number of usermade errors, user-made errors that cover mismatches of what the user thinks is what 
TABLE 2: Usability distribution of the use of the online platform e com among students of PPNI West Java $(n=34)$

\begin{tabular}{l|c|c|}
\hline Variable & Frequency (n) & Percentage (\%) \\
\hline Learnability & 10 & 29.4 \\
\hline Non-Easy & 24 & 70.6 \\
\hline Easy & & \\
\hline Efficiency & 3 & 8.8 \\
\hline Incorrect & 31 & 91.2 \\
\hline Correct & & \\
\hline Memorability & 0 & 0 \\
\hline Non-Memorable & 34 & 100 \\
\hline Memorable & & \\
\hline Errors & 11 & 32.4 \\
\hline Major Errors & 23 & 67.6 \\
\hline Minor Errors & & \\
\hline Satisfaction & 0 & 100 \\
\hline Negative & 34 & \\
\hline Positive &
\end{tabular}

the system represents. All respondents remain satisfied with this application, although it needs improvement in several aspects (100\%). Satisfaction is defined as freedom from inconvenience, and a positive attitude towards product use or a subjective measure of how users feel about using the system.

Measuring usability means measuring the effectiveness, efficiency, and user satisfaction. For this reason, two ways can be done, namely by relying on the assumptions of the program maker or himself and using usability metrics. The usability measurements can be used to obtain input from data, be more objective than one's own opinion, clarify problems, predict actual product use, and provide illustrations to management based on facts [14]. Understanding applications' usage is expected to improve questioning techniques and, consequently, higher quality history taking $[10,16]$. It is in line with previous research that states that nursing students must have good critical thinking. Besides that, by requiring students to pass a test in UJIKOM, nursing education institutions must prepare their students well $[18,19]$. It is hoped that the excellent user acceptance in running the e-KOM, the application built by researchers, is expected to be a provision for students to take competency tests for students in the health profession. 


\section{Conclusion}

The usability test showed all the attributes of the platform have good acceptance value by the user. The average is above the value 3 , so it can be said that the android application software that has been made has a usability aspect value. All groups use very acceptability because android is very easy to learn well understood by users. It can be concluded that this application has good usability, as evidenced by the high score of the five usability aspects. Application development by minimizing errors and setting functions and menus following the target user of this application is expected to increase the usability and readiness of this application for use on a larger scale.

\section{References}

[1] Sapeni, M. A.-A. R. and Said, S. (2020). The Effectiveness of Case-Based Learning in Increasing Critical Thinking of Nursing Students: A Literature Review. Enfermería Clínica, vol.30, issue. 2, pp. 182-185. http://doi.org/10.1016/j.enfcli.2019.07.073

[2] Keemink, Y., et al. (2018). Illness Script Development in Pre-Clinical Education through Case-Based Clinical Reasoning Training. International Journal of Medical Education, vol. 0, issue. 9, pp. 35-41. http://doi.org/10.5116/ijme.5a5b.24a9

[3] Hong, S. and Yu, P. (2016). Comparison of the Effectiveness of Two Styles of CaseBased Learning Implemented in Lectures for Developing Nursing Students' Critical Thinking Ability: A Randomized Controlled Trial. International Journal of Nursing Studies. vol. 68, pp.16-24. https://doi.org/10.1016/j.jinurstu.2016.12.008

[4] Reese, C. E. (2011). Unfolding Case Studies. Journal of Continuing Education in Nursing, vol. 42, issue 8, pp. 344-345. http://doi.org/10.3928/00220124-2011072204

[5] West, C., Usher, K. and Delaney, L. J. (2012). Unfolding Case Studies in PreRegistration Nursing Education: Lessons Learned. Nurse Educ Today, vol. 32, issue 5, pp. 576-580.

[6] Bowman, K. (2017). Use of Online Unfolding Case Studies to Foster Critical Thinking. Journal of Nursing Education, vol. 56, issue 11, pp. 701-702, https://doi.org/10.3928/ 01484834-20171020-13.

[7] Meiers, J. and Russell, M. J. (2019). An Unfolding Case Study: Supporting Contextual Psychomotor Skill Development in Novice Nursing Students. International Journal of Nursing Education Scholarship, vol. 16, issue. 1, pp. 1-9. http://doi.org/10.1515/ijnes2018-0013. 
[8] Carr, K. C. (2015). Using the Unfolding Case Study in Midwifery Education. J Midwifery Womens Health, vol. 60, issue. 3, pp. 283-290. http://doi.or/10.1111/jmwh.12293.

[9] Palermo, C., et al. (2019). Using Unfolding Case Studies to Better Prepare the Public Health Nutrition Workforce to Address the Social Determinants of Health. Public Health Nutr, vol. 22, issue 1, pp. 180-183, https://doi.org/10.1017/ S1368980018002811.

[10] Sinclair, P., Kable, A. and Levett-Jones, T. (2015). The Effectiveness of InternetBased E-Learning on Clinician Behavior and Patient Outcomes: A Systematic Review Protocol. JBI Database of System Reviews and Implementation Reports, vol. 13, issue 1, pp. 52-64, https://doi.org/10.11124/jbisrir-2015-1919.

[11] Lund, A. and Lund, B. A. M. (2001). Measuring Usability with the USE Questionnaire Measuring Usability with the USE Questionnaire. Retrieved $20^{\text {th }}$ October, 2020 from https://www.researchgate.net/publication/230786746.

[12] Maramba, I., Chatterjee, A. and Newman, C. (2019). Methods of Usability Testing in the Development of eHealth Applications: A Scoping Review. International Journal of Medical Informatics, issue. 126, pp. 95-104. http://doi.org/10.1016/j.jimedinf.2019. 03.018

[13] Methasari, I. G. and Hayatin, N. (2017). Analisis Usability Terhadap Sistem Lective Gegulang Berbasis Use Questionnaire. In Seminar Nasional Teknologi Dan Rekayasa (SENTRA). Malang; November 2017.p. 1-8

[14] Santoso, J. (2018). Usability User Interface and User Experience Media Learning Dictionary Kolok Bengkala Based on Android. Journal of Systems and Informatics, vol. 12, issue. 2 , pp. 174-181

[15] Mclean, S. (2016). Case-Based Learning and its Application in Medical and HealthCare Fields: A Review of Worldwide Literature. Journal of Medical Education and Curricular Development, vol. 3, issue 4, pp. 39-49.

[16] Missen, K., McKenna, L. and Beauchamp, A. (2014). Graduate Nurse Program Coordinators' Perceptions of Role Adaptation Experienced by New Nursing Graduates: A Descriptive Qualitative Approach. Journal of Nursing Education and Practice, vol. 4, issue 12, pp. 134-141.

[17] Perez, E., et al. (2015). Critical Thinking in Nursing: Scoping Review of the Literature. Journal of Nursing Practice, vol. 21, issue 6, pp. 820-830.

[18] PNUK. (2019). Implementation of the Competency Test for Students in the Field of Health Personnel for the First Period of 2019. Retrieved from http://ukners.ristekdikti.go.id/berita/115-Pelimplementation-Uji-CompetencyStudent-Field-Health-Personnel-Period-I-Year-2019. 
[19] Ward, T. and Morris, T. (2016). Think Like A Nurse: A Critical Thinking Initiative. The ABNF Journal, vol. 27, issue 3, pp. 64-66. 